Indian Ocean, the Malay Archipelago, the Mediterranean and Africa. He also details the new geodetic methods they discovered and the numerous coordinate tables they generated, which influenced European maps well into the eighteenth century.
The abundance of material brought together in this book is truly awesome. The three handsomely produced volumes are thoroughly indexed. With so many novelties, Sezgin's book will no doubt be controversial. But therein lies an added value: it will provoke an even more thorough search for additional data on the history of a subject that had long stagnated. A. M. Celal Șengorr is in the Department of Geology, Istanbul Technical University, and the Eurasian Institute of Earth Sciences, Ayazaga, 34469 Istanbul, Turkey.

THEATRE

\section{Would the real Mr Feynman...?}

\section{Clever Dick}

written and directed by Crispin Whittell

At Hampstead Theatre, London, until 17 June

www.hampsteadtheatre.com

\section{Richard Webb}

"Confusion. See, confusion ain't a sickness I suffer from. I take my strength from the simple love of my country and faith in my God." Self-doubt does not cloud the horizons of 'Fat Man' Sergeant Whitey Stokes, CounterIntelligence Corps, on the evening of 17 June 1945. The Red spy he thinks he's interrogating - the physicist Richard Feynman - on the other hand, is very confused. He hasn't slept for 58 hours. On his way to Los Alamos, he took the wrong turning at Albuquerque because of a congenital inability to tell left from right. Mistaking him for her beau 'Little Boy', the 18-year-old receptionist of his hotel has just tried to go to bed with him.

Thus, in Clever Dick, playwright-director Crispin Whittell lays out the ingredients for a classic farce. But the sobriquets of two characters reveal a deadly serious setting: Little Boy and Fat Man were the nemeses of Hiroshima and Nagasaki. One month after Whittell's imagined encounter in a New Mexico hotel room, the first atomic bomb is to be tested.

Hence Feynman, played by Adrian Rawlins with a nervous, nerdy energy that contrives to make his slight build seem lanky. His busy hands conduct to a score with some diverting passages ("So he knows a lot of Communists. I know a lot of women, but that doesn't make mea woman ${ }^{\text {}}$ ) and frenetic, slapstick moments - topped by a spectacular re-entry for Fat Man, amply portrayed by Corey Johnson, that literally brings the house down.

But ultimately this farrago is, like that ceiling, a false plasterboard mishmash. Its profound periods are not deep enough nor its farcical moments sustained enough to carry the audience, which is only truly captivated by a moment of pathos towards the end when Feynman reveals the real reason for his confusion: the death, the evening before, of his wife from tuberculosis. Science enters in the second half only in a shampoo-ad-style 'here's the science bit' as a fig-leaf for the play's intellectual flaccidity. Feynman, rigorous scientist and, above all, great communicator of modern physics, would, one suspects, not have been pleased.
Indeed, what is Feynman doing here? He is pitched - as a participant in the Manhattan project that developed the atom bomb - as the voice of nuanced moral doubt against the dumb certitude of the gung-ho Stokes with his unshakeable faith in God and the gun (an intended contemporary resonance). But this is a role that Feynman never played: his principal extramural contribution to the Manhattan project lay not in breast-beating but bongo-beating and the apocryphal cracking of every safe containing nuclear secrets on the Los Alamos site. He was ever, in Freeman Dyson's words, "half genius and half buffoon". As he said in a 1981 interview: "What I did — immorally, I would say - was to not remember the reason that I said I was doing it, so that when ... Germany was defeated, not the singlest thought came to my mind ... I simply didn't think, okay?”

Michael Frayn's Copenhagen left a great appetite for plays that deal with the interface of science and morality. This is Whittell's second foray onto such territory, following his generally well-received 2003 play Darwin in Malibu. The safe-cracking, wisecracking womanizer Feynman is a headline-grabbing front man for a second attempt. In this case the result is, charitably put, confused.

Richard Webb is the physical-sciences News and Views editor at Nature.

\section{On Seeing: Things Seen, Unseen and \\ Obscene \\ by F. Gonzalez-Crussi \\ Overlook/Duckworth: 2006. 224 pp. \\ $\$ 24.95 / £ 14.99$}

\section{Richard Gregory}

Frank Gonzalez-Crussi is a pathologist, well versed in how we see, although here he focuses on what we see, and on what, for obscure reasons, are rejected by eye and mind. This disportment in art and medicine is rewarding thanks to the power of the writing to carry the reader safely to "things seen, unseen and obscene". These include the body, viewed from inside and outside with a medical gaze; French literature and history (with a hilarious account of the start of the Revolution triggered by

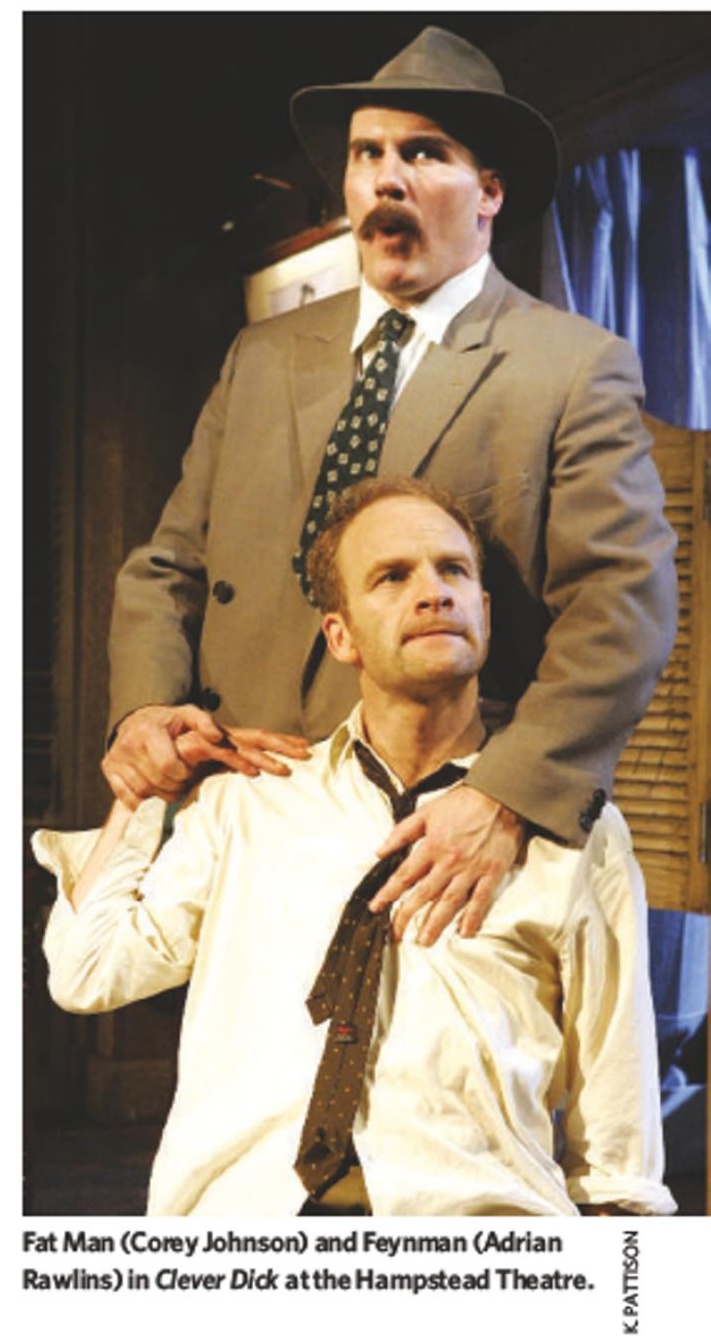

The eye of the beholder

a pair of royalist voyeurs); belief; and sin. A principal theme is the attraction and repulsion of the anatomical focus of femininity to the male eye, which induces a fascinated fear, rather like standing on the edge of cliff.

Gonzalez-Crussi suggests reasons for why anatomy was so slow to develop as a science, including the inability to make effective use of detailed knowledge before anaesthetics. But has a lack of rapid use impeded other sciences? If it is inhibition associated with prurience that held back the study of anatomy, it is unfortunate that this book was not available centuries ago. It can be enjoyed for its broad learning, and its broad humour.

Richard Gregory is in the Department of Experimental Psychology, University of Bristol, Bristol BS81HH, UK. 